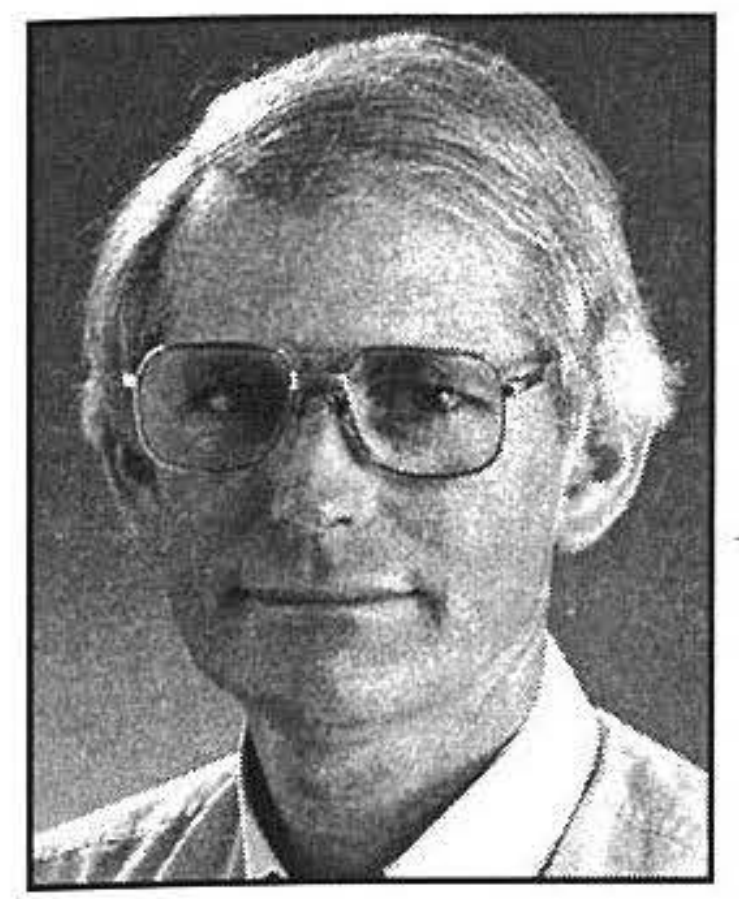

\title{
THE FACTOR SHARES DEBATE: AN UPDATE
}

\author{
Geoff Bertram
}

\author{
School of Economics and Finance \\ Victoria University of Wellington
}

The division of the national product between capital and labour is an old topic in economic theory but since the ending of New Zealand's old system of national accounts which were prepared on an income basis, it has been harder to track the trends in factor shares in New Zealand. The paper assembles figures to see whether there is any sign that the change in political conjuncture (and hence potentially the balance of power in the labour market) in the mid-1980s had any effect on factor shares in the product. The hypothesis is that the 1984 election marked the end of a long period of relative gains for labour at the expense of capital, and was followed in the following two decades by a trend in the other direction, to which the Employment Contracts Act might have contributed. As usual the numbers speak only softly and have to be interpreted with the greatest caution.

Keywords: Factor shares, national product, national accounts, labour, capital

At the end of the 1970s two papers appeared arguing that a rising wage share had put pressure on the profit rate in New Zealand, and that this helped to account for the rise in unemployment which was a major new phenomenon at that time. This triggered a considerable debate among New Zealand economists during the 1980 s over the relationship between the real wage, labour productivity, unemployment, and economic growth. Most of that debate was concerned with the relationship between the real wage and unemployment in the short-to-medium term, rather than with capital accumulation and long-run growth performance. McDonald (1978), however, quoted extensively and approvingly from a Swedish study which had argued for incomes policy to keep the wage/profit distribution within a target 'corridor' over time, given that that

\begin{abstract}
a shift in the distribution in favour of wage earners at the expense of business firms ... has an effect in the first instance on the capacity of enterprises to finance investment for increased productivity and the expansion of capacity. ... [The equity-debt ratio and profitability] limit the extent to which the distribution of income can be shifted in favour of wage earners without leading to consequences which in the long run also operate adversely for wage earners, in the form of a lower rate of economic growth...
\end{abstract}

McDonald's central distributional claim was that the profit share of net output had fallen from $36 \%$ in the early $1960 \mathrm{~s}$ to only $29 \%$ by the second half of the 1970 s, while the wages and salaries share had risen from $47 \%$ to $56 \%$ over the same period. He acknowledged that a rising tax wedge on labour meant that "the increase in Salaries and Wages After Tax was much slower ... and was in line with GDP/ NDP growth rates in the $1970 \mathrm{~s}$ ", but for the purposes of his main argument he relied on the increasing share of pretax wages and salaries as evidence of a squeeze on profits.

The relative roles of the real income wage (that is, the after-tax wage rate deflated by the CPI), and the incidence of income tax on wage costs, in raising the cost of labour to employers in the 1970s was explored further by Bertram and Wells (1983), Easton (1983), and Bertram (1985). The data appeared to show that in after-tax terms the wage/ salary share of NDP had risen by about five percentage points during the tight labour market of the 1950s but thereafter had stabilised at around 50\%; some upward trend had appeared in the Old National Accounts series which were discontinued after 1978, but was absent in the new SNA accounts that appeared in 1978 and were soon backdated to 1962. Both Easton (1983) and Bertram (1985) noted that while the after-tax labour share appeared constant, the pre-tax share did not, which raised interesting questions about whether 'Bowley's Law' of constant factor shares based on the technical parameters of the aggregate production function could be applied to New Zealand.

The perception among policymakers in both Australia and New Zealand that some sort of 'profit squeeze' had occurred in the 1970s, echoing similar concerns in the UK, led to a perceptible change in the political climate in the 1980s. Thatcher's frontal assault on the trade unions in Britain had a somewhat muted echo in New Zealand, especially while Labour was in power between 1984-90, but organised labour nevertheless was pushed increasingly onto the defensive, while policymakers focused openly on measures aimed to improve profitability. The Employment Contracts Act 1991 marked the high tide of a sustained ideological and political offensive by employers against the unions; but the turning of the tide that led to the ECA 
has to be dated much earlier, in the early and mid $1980 \mathrm{~s}$ when Thatcherite views became widespread among New Zealand business and policy elites.

One of the econometric surprises of the 1990s has been the lack of clear evidence that the ECA itself actually affected labour market outcomes - either real wages or unemployment - in any very dramatic way. The hypothesis with which I embarked on a new exploration of the factorshares data was that economy-wide sea changes in the balance of social forces take place over longer time frames than five years or so, and that the ECA was only part of a longer swing in that balance in New Zealand. Hence I set out to look for signs of a turning of the tide in the early 1980s.

Implicit in my approach to the topic is provisional acceptance of the Ricardian hypothesis that in a growing economy not settled into a stationary state there is a degree of indeterminacy in the relative shares of labour and capital in the product, over a range bounded by the "subsistence wage rate" and the zero-investment threshold rate of return.

A second possible hypothesis which I failed to frame at the outset was implicit in our 1983 discussion of a hypothetical profit squeeze:

A rise in the real wage which increases the labour share of the social product may squeeze the profit share, and thereby force down the rate of profit. [One of] the conditions for this to occur [is] ... that the squeeze affects profits rather than the shares of the State or foreigners...

The reference to 'foreigners' indicates that when referring to 'profits' we were thinking of the profits secured by domestically-resident capitalists, as distinct from capitalists in general. However it is clear from the context of the passage just quoted that the profitability of domestic capital can potentially be squeezed from three directions, not just by wage push. An increasing tax wedge had clearly been a feature of the 1970 s and contributed to the passionate business advocacy of tax cuts in the 1980s. A rising share of profits captured by foreign interests could also squeeze the economic surplus accruing to domestic owners and hence make economic growth increasingly dependent upon the willingness of foreign interests to plow profits back into New Zealand in preference to alternative opportunities elsewhere in the global economy. This, as will be seen, turns out to be an important, albeit unplanned, conclusion of this study.

\section{Some Numbers}

We begin by disaggregating total factor payments (GDP at factor cost) among the three familiar national-accounts aggregates 'compensation of employees' (that is, wages and salaries), 'depreciation', and the residual 'operating surplus' which is as close as the current SNA national ac-

\section{Figure 1. Pre-Direct-Tax Shares of GDP at Factor Cost}

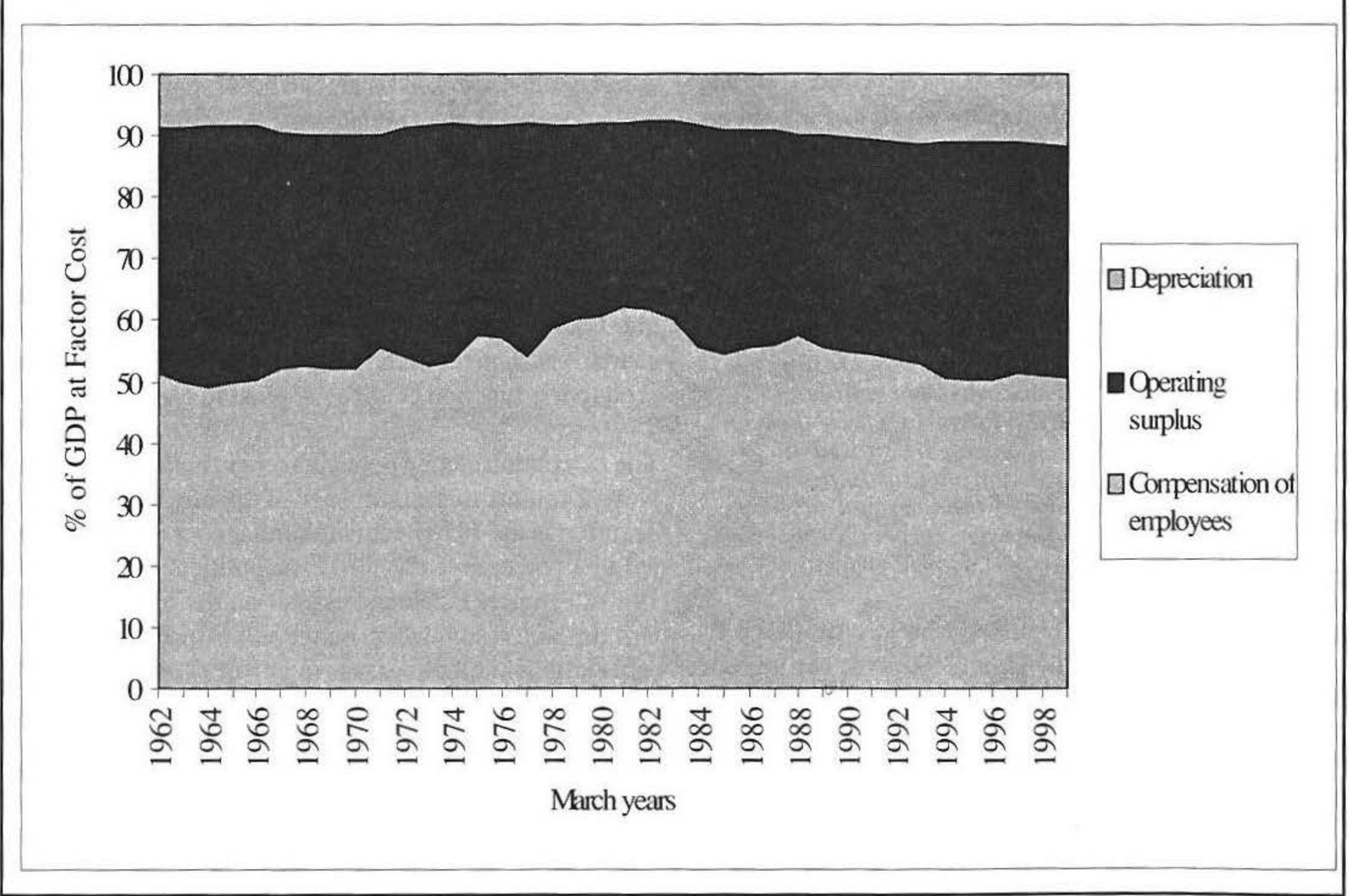


counts take us to a profit share. Figure 1 shows the picture,. The data are from Table A5.1 which together with the appendices are available from the author.

The motivation for my initial hypothesis is immediately evident from this chart. The pre-tax data for wages and surplus (which includes profits, rents, and other components such as self-employed incomes and imputed rents of owner-occupied housing) reflect, as McDonald had argued, an apparent wages-led squeeze on profits in the 1970 s reversed by a swing in the other direction after 1982. The wages share began the $1960 \mathrm{~s}$ at $50 \%$, rose to $62 \%$ by 1982 , and had been driven back down to $54 \%$ by the end of the $1990 \mathrm{~s}$. There is no break in the trend at the time of the ECA.

Old hands will immediately know, however, not to trust these high-level SNA aggregates, especially considering the mixed bag of income claims that go into 'operating surplus'. It is essential to disaggregate the data further.

A first step in this direction is to separate out the growing wedge of direct taxation on both capital and labour. This changes the picture to that in Figure 2 (for data see Table A5.2).

In after-tax (income) terms, in the two decades before 1982 the labour share more or less held its own, but with no upward trend to match that of the pre-tax (product) wage seen in Figure 1. The after-tax wage share was $44.7 \%$ in $1962,43.2 \%$ in 1972 , and $44.0 \%$ in 1981 prior to the Freeze. Thereafter the after-tax wage and salary share came under sustained downward pressure, falling to $34.4 \%$ by 1996, after which it stabilised at the new lower level. There is no break in trend corresponding to passage of the ECA.

After-tax operating surplus was clearly squeezed (by the State rather than organised labour) during the two decades prior to 1982 . The surplus share fell from a peak of 32.6 in 1962 to a trough of $22.7 \%$ in 1981 , following which it rebounded back to $31 \%$ by 1994 and has stabilised at that level since.

In summary, the combined after-tax share of direct factor claims as represented by the two major national-accounts aggregates dropped from about $83 \%$ to $75 \%$ by the early $1980 \mathrm{~s}$ as the tax wedge widened, then stabilised and picked up slightly to about $77-78 \%$ by the end of the 1990 s. The squeeze went first onto operating surplus in the 1970s, then was progressively transferred to after-tax wages and salaries from the early-mid 1980s. Figure 3 shows the trends in the two shares. Here again there is some support for the hypothesis of a change in conjuncture adversely affecting the wage share from the early-mid 1980s through the 1990 s, with a loss of about $10 \%$ of GDP to the other claimants contained within the national accounts aggregates

\section{Figure 2. After-Tax Shares of GDP at Factor Cost}

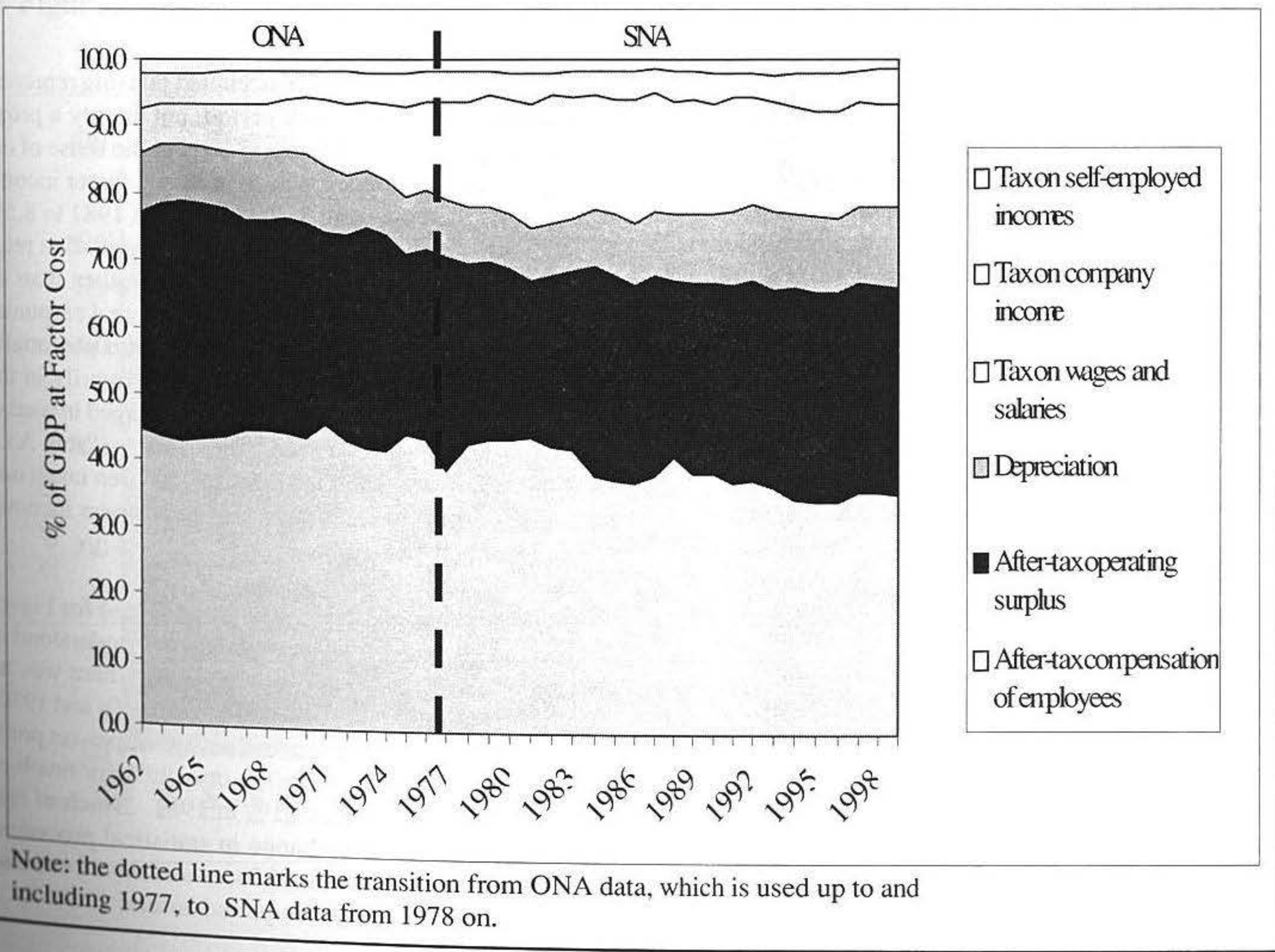




\section{Figure 3. Shares of After-Tax Compensation of Employees and After-Tax Operating Surplus in GDP}

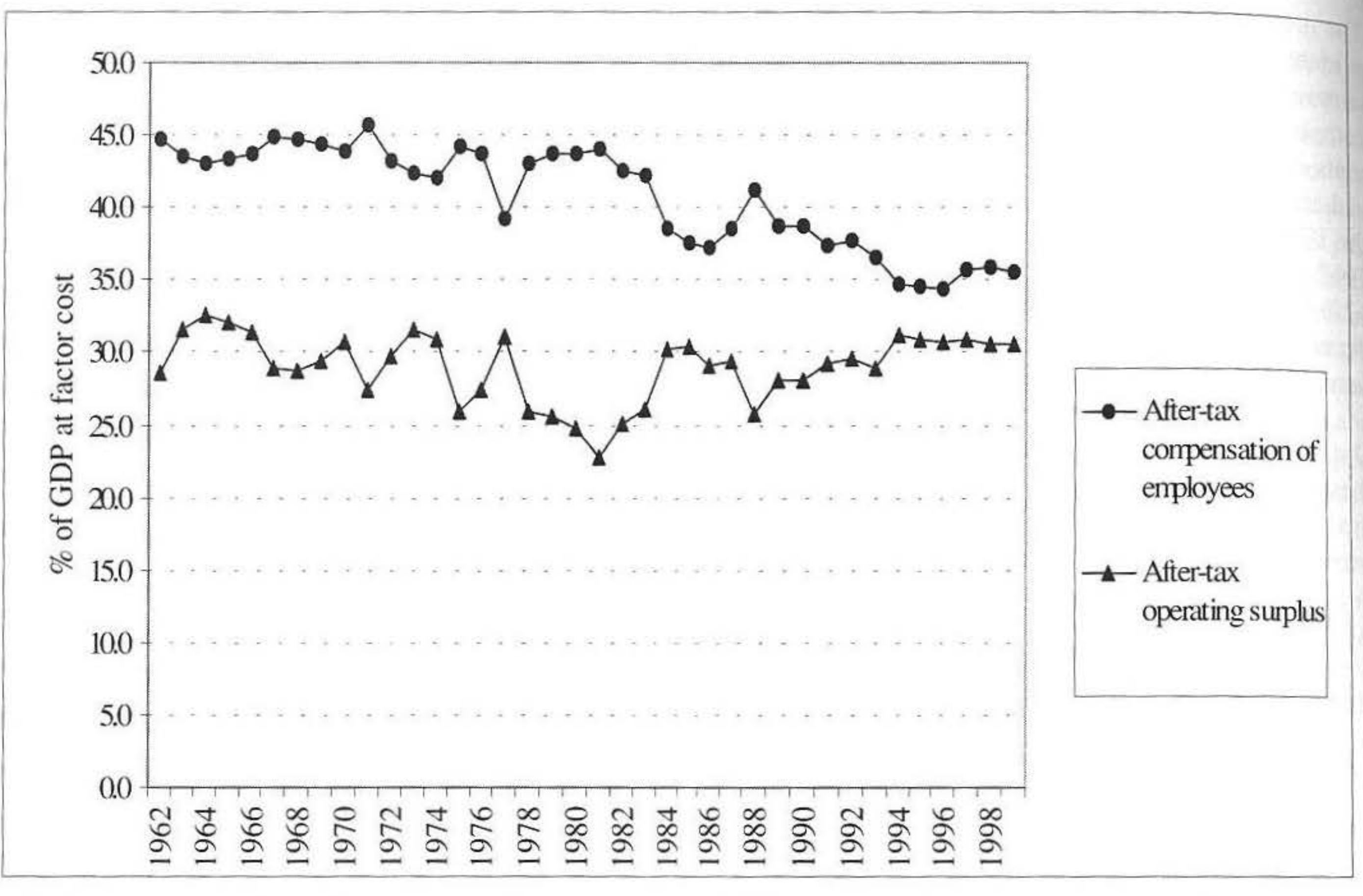

'depreciation' and 'operating surplus.'

To say anything satisfactory about the profit share, we have to break down the undifferentiated residual called 'operating surplus'. Included in this component are selfemployed income, imputed rents on owner-occupied housing, profits earned by overseas owners of New Zealand firms, errors and omissions, and residual profits and rents flowing to domestic capitalists. Table A5.3 presents a provisional decomposition, with errors and omissions still remaining hidden inside the after-tax surplus accruing to domestic capitalists. Figure 4 plots the results and draws attention immediately to the expansion of overseas profits and owner-occupied housing relative to the other components of Operating Surplus.

Table A5.4 then shows the components of gross surplus as percentages of GDP at Factor Cost and the results are plotted in Figure 5. The recovery of gross surplus from $38 \%$ of GDP in 1981 to $49 \%$ by 1994 is immediately apparent.

In Figure 5 it is apparent that the three growing shares within operating surplus were depreciation, owneroccupied housing, and foreign profits. Depreciation is appropriately netted out before looking seriously at factor shares; I have left it in up to this point only because the national-accounts estimate for depreciation is notional only, and for some purposes it is better to look at the gross surplus given that this is the primary source of finance for gross investment. We have, however, no way of decomposing depreciation between domestic and foreign owned assets and in Table A5.5 and Figure 6 it is taken out to leave shares of NDP at factor cost.

The imputed rentals on owner-occupied housing represent not actual production in each period, but simply a proxy for the welfare gained by home owners in the sense of not having to pay house rent out of their actual factor income receipts. Its increase from $2.8 \%$ of NDP in 1981 to $8.5 \%$ by 1999 reflects the rise in house prices and market rents relative to other prices in the economy, rather than an increase in its share of the annual flow of real resources and product. Its inclusion in operating surplus potentially distorts the picture, since our interest is primarily in the share of net profit accruing to capitalists engaged in market production using wage labour. Therefore in Table A5.6 and Figure 7 owner-occupied housing has been taken out, leaving the profits of capitalists and the business incomes of the self-employed.

In a final step, the self-employed are excluded for Figure 8 , which shows the profits share as usually understood in classical growth theory. We now find that there was no squeeze on profits in this sense during the 1960s and $1970 \mathrm{~s}$ according to these figures; on the contrary, the pre-tax profit share rose from $20.3 \%$ in 1960 to over $25 \%$ for much of the 1970 s, before falling to $21 \%$ in 1981 . Much of this apparent fall reflects the change in statistical procedure when SNA accounts began in 1978, so one should not read anything too dramatic into the period around 1980 . 


\section{Figure 4. Decomposition of Operating Surplus: \$ million}

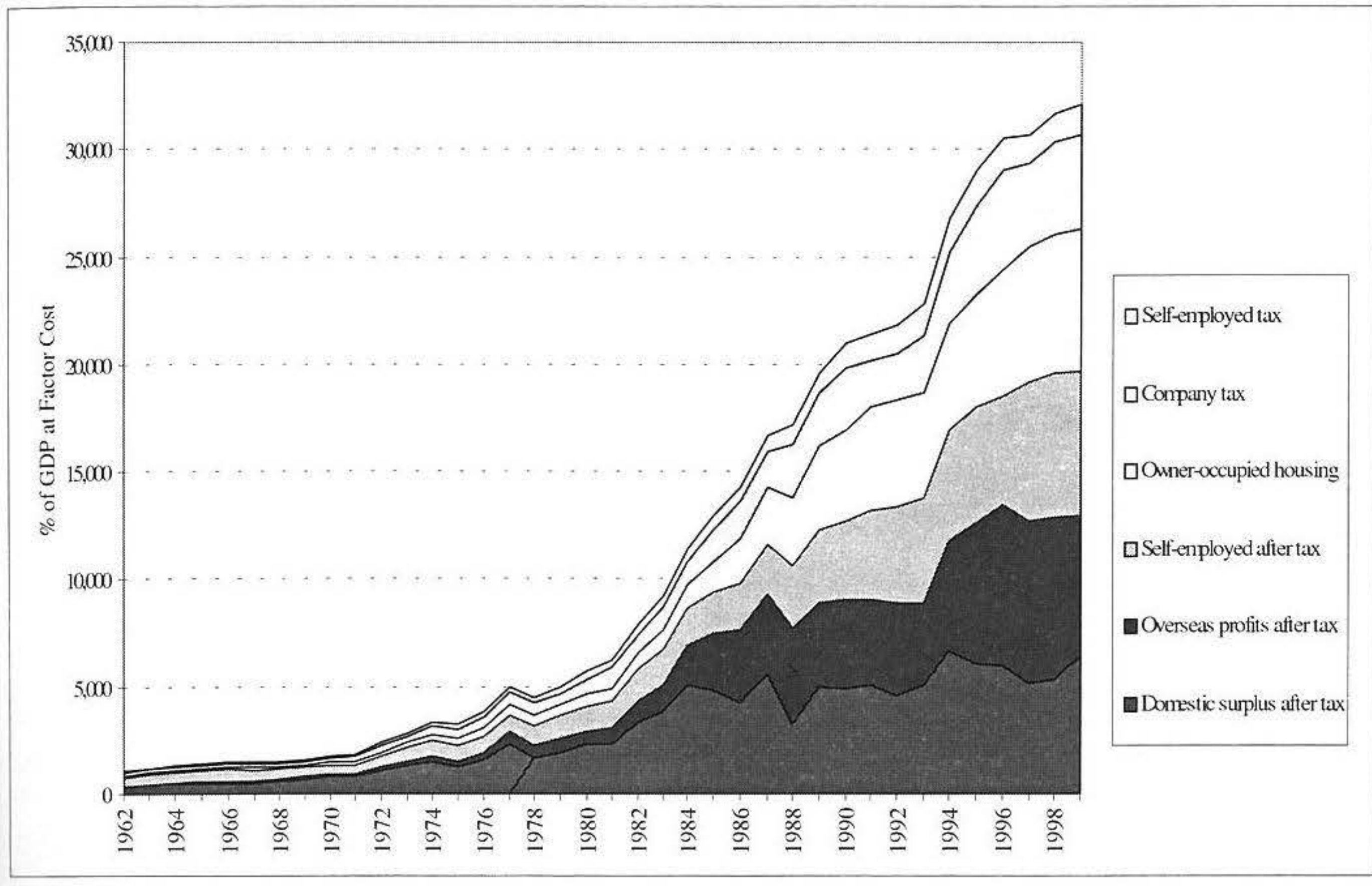

Figure 5. Decomposition of Gross Surplus (Operating Surplus Plus Depreciation)

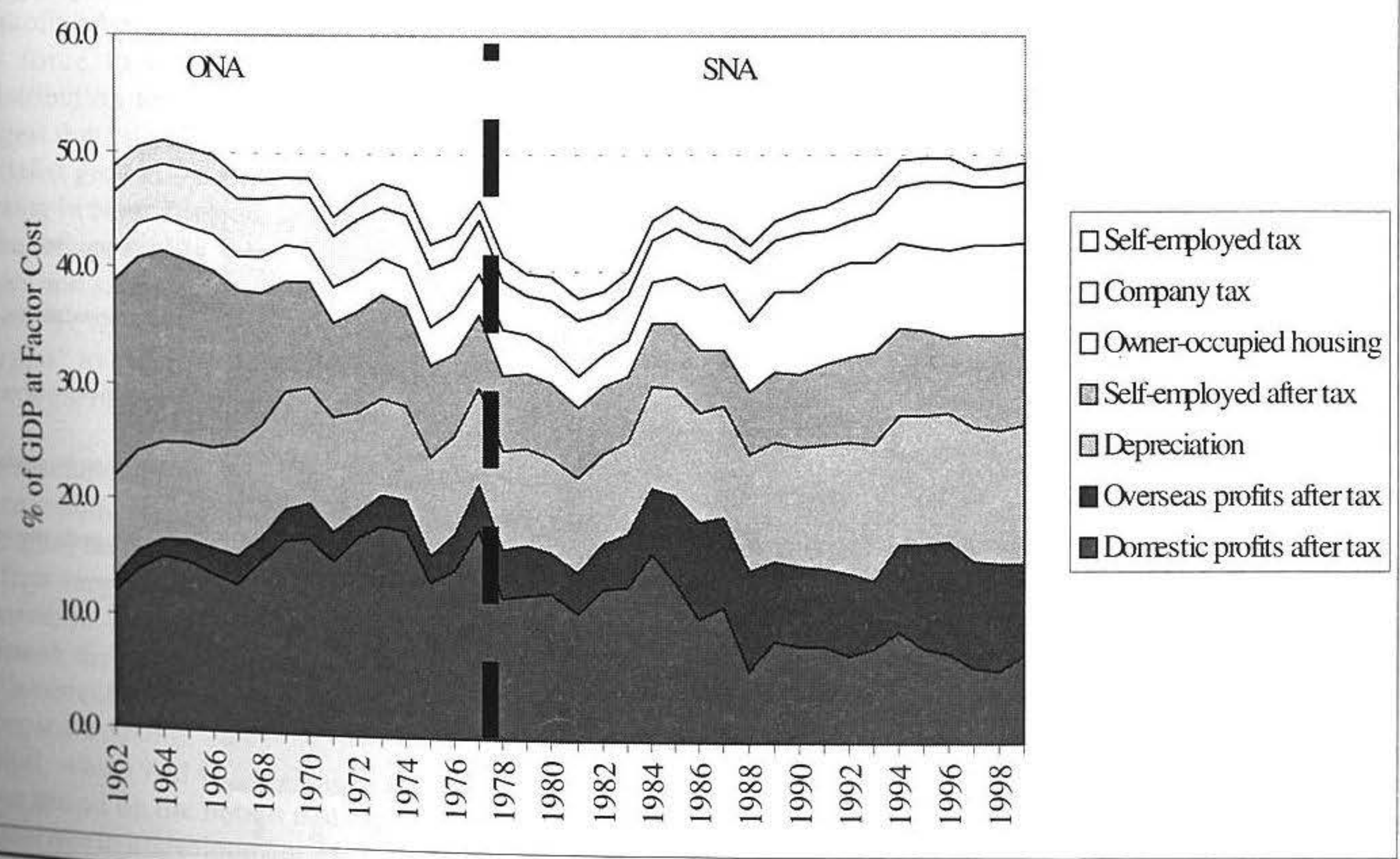


Figure 6. Operating Surplus Components as \% of NDP

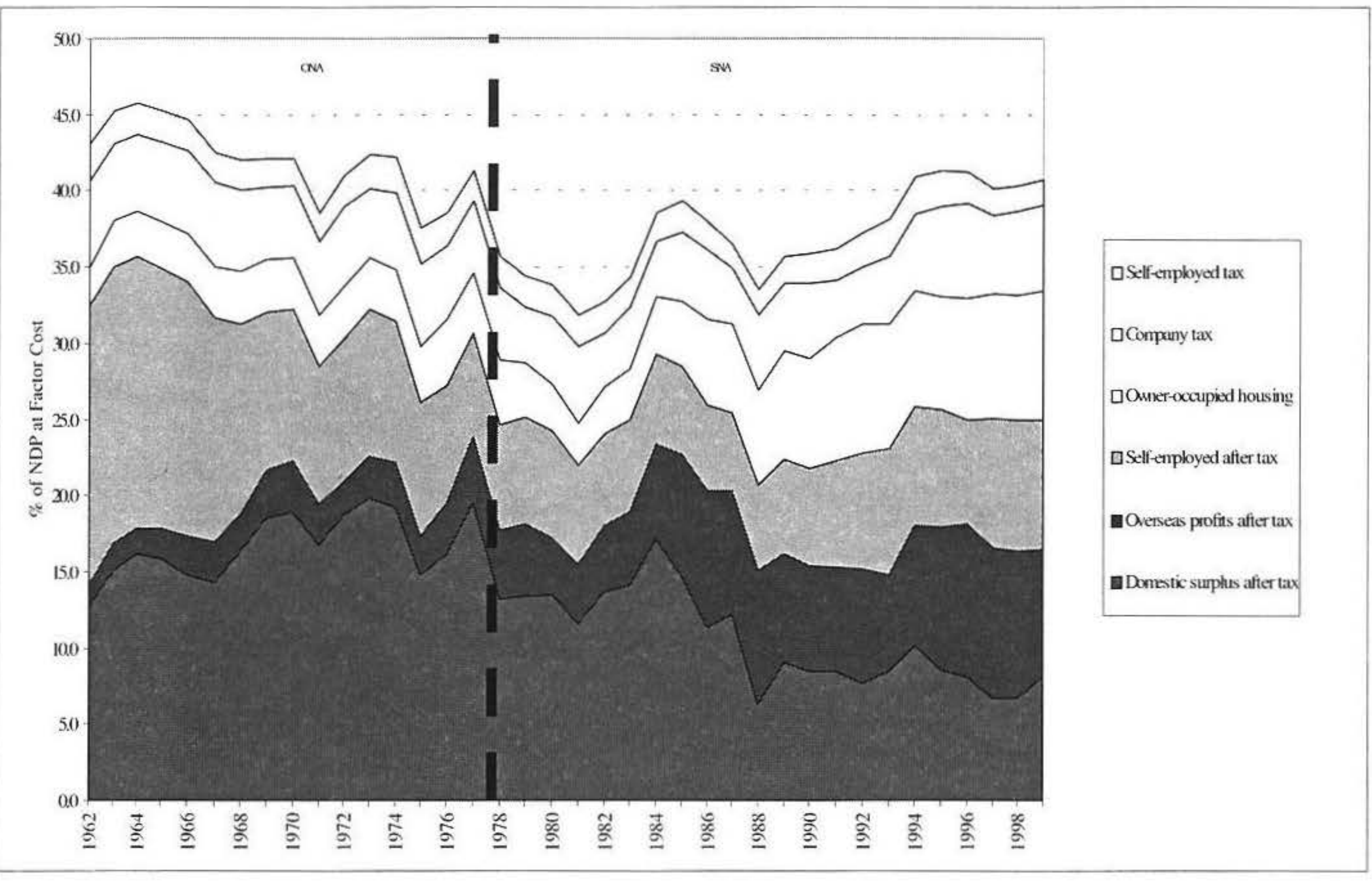

\section{Figure 7. Operating Surplus Components Excluding owner-Occupied Housing}

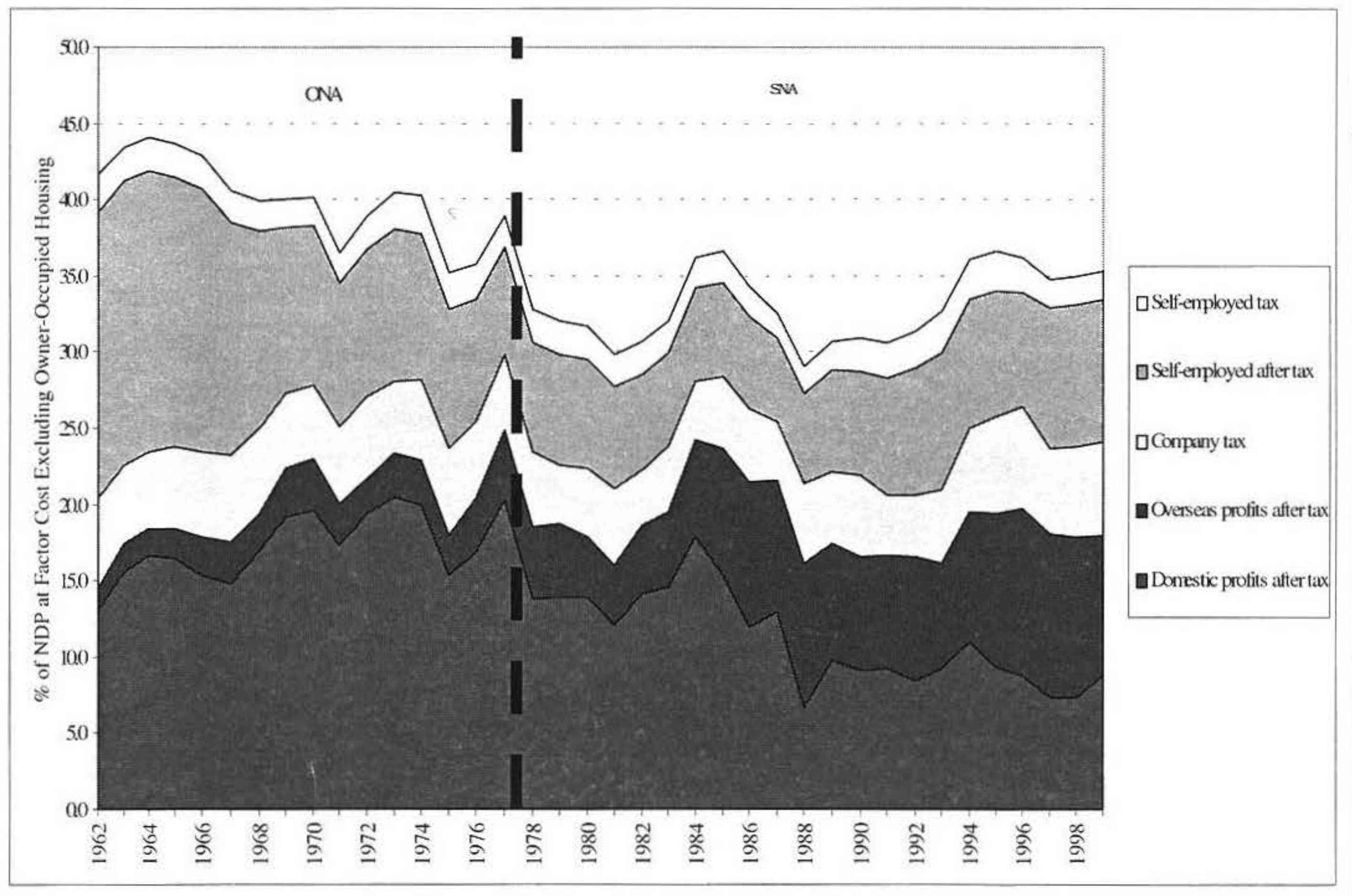




\section{Figure 8. The Changing Shares of the Net Profit Share}

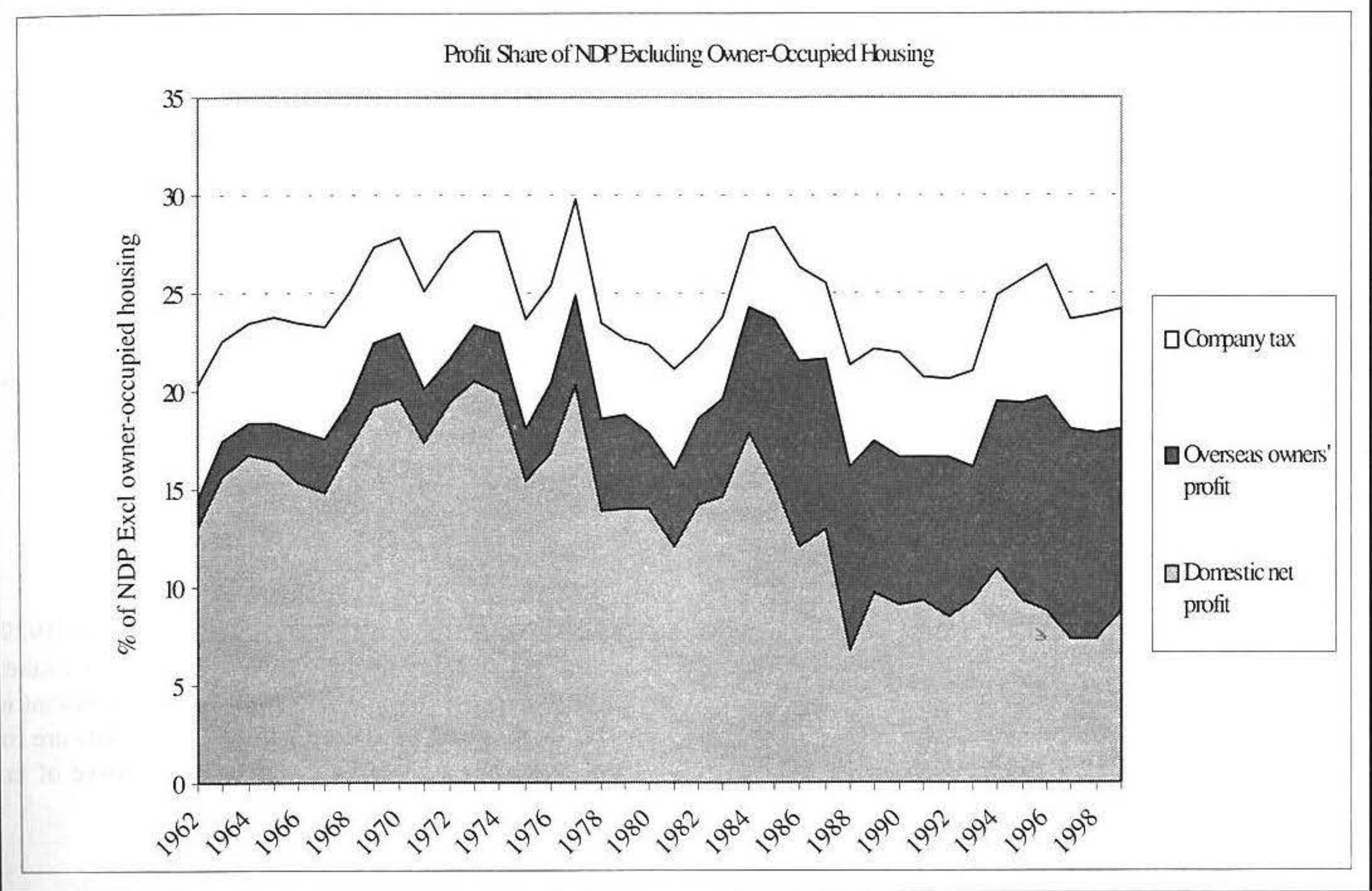

Clearly since the early 1980 s the profit share has held steady but has exhibited pro-cyclical fluctuations, rising in booms and falling in recessions. Two features stand out starkly from Figure 8, however, firstly the structural reforms which began in the mid-1980s had no apparent effect on the aggregate profit share over the long haul. Insofar as the profit-squeeze diagnosis of slow economic growth had any force in the early 1980 s, there has been no redistribution towards capital since then, which might suggest that one of the necessary conditions for reviving capitalist growth - a rising share of net profit - has been missing in New Zealand. This is all the more intriguing given the apparently sustained political offensive against wages and salaries throughout the period, seen earlier in Figure 3. It now emerges that the apparent gains to "surplus" in Figure 3 were due to rising house prices, not improving real profitability in production.

The second major stylised fact to emerge from Figure 8 is the near-euthanasia of domestic capital, as the deregulation of capital markets and privatisation of state assets have shifted large swathes of the economy into foreign ownership. The after-tax profit share of overseas owners overtook the share of domestic capital decisively in 1995 and is currently running at $9-10 \%$ of NDP excluding owneroccupied housing, compared with $7-8 \%$ for domestic capital, which had had a $21 \%$ share in the 1970 s. For those reared on the notion that national capital has some special role in a development and growth process, this trend would be cause for consternation. Even in an era of globalisation, the question naturally arises whether there is any behavioural difference between foreigners and local capitalists in the ways they allocate their locally-captured profits. Clearly the immediate future of economic growth in New Zealand now lies in the hands of foreign investors to an extent that would have been unthinkable twenty years ago.

The rising share of profits to overseas owners in Figure 8 is, of course, simply the story of the balance of payments current account in the 1990s - indeed, our estimate of that share was obtained using the balance of payments series for "property and entrepreneurial income to rest of world". There is a whole story to be told about the relationship between the accrual of those profits in the balance of payments statistics, and their actual disposition between repatriation and acquisition of New Zealand dollardenominated assets. That, however, is the subject for another paper.

\section{Conclusions}

There are four main conclusions we can draw from the above. Firstly the share of wages and salaries has unequivocally fallen through the period of free-market reforms, but the Employment Contracts Act looks to have been simply a symptom of the general trend, not a significant event in its own right.

Secondly the profit share, in the sense of company profits accruing to domestic and foreign owners of corporate enterprises, has barely changed over the past half-century (allowing for the one-off statistical shift in 1978 when the 
national accounts methodology changed). The profit share moves pro-cyclically, and the past twenty years have witnessed a massive transfer of the economy's profits flow out of the hands of local owners and into foreign hands, to the point where domestic capitalists are now minority participants in the aggregate profit share.

The third conclusion is that the self-employed income suffered a massive squeeze from the early 1960 s to the late 1970 s (down from $19 \%$ to $7 \%$ of NDP excluding owneroccupied housing, in after-tax terms - see Table A5.6) and has rebounded only slightly in the 1990 s (back to $9 \%$ ).

Fourthly, most of the apparent rise in the share of operating surplus is attributable to rising house prices and a corresponding increase in the share of imputed rents. Consequently, reclassification of self-employed business income and owners-occupied housing can quite radically change the picture of the distribution of the total net product among the four claimants Labour, the State, Foreign Capital, and Domestic Capital. See Figures 9-11.

\section{Future Research}

The implications of changing factor shares for economic growth remain an intriguing topic for further investigation. The era of a falling wage share from 1982 on corresponded to a period of rising unemployment and slow growth. However, the failure of the profit share to rise as the labour share fell may help to explain why the squeeze on labour incomes had such a poor payoff in terms of capitalist rejuvenation. In addition, the era of radical attempts to wither the State left the tax wedge on factor incomes in general virtually unchanged.

\section{Notes}

$1 \quad$ McDonald (1978); Rosenberg (1980). Discussion of the significance of these papers, together with a survey of the subsequent "real wage debate" up to the early 1990s, is in Chapple (1993) Chapter 8 pp.170-189. Easton (1990) also provides a survey.

Edgren et al (1973) quoted in McDonald (1978) pp.6-7.

3 McDonald (1978) p.17 and p.24.

$4 \quad$ McDonald (1978) p.9.

$5 \quad$ Rima (1996) p.310 argues, using US data 1929 1990 , that "when institutional changes are taken into account, the wage share remains constant in the range of 73 to 76.8 percent". The data are for wage costs faced by employers, inclusive of tax and social security.

6 Cf Rowthorn (1980).

Figure 9. The Four Claimants with Self-Employed Treated as "Labour"

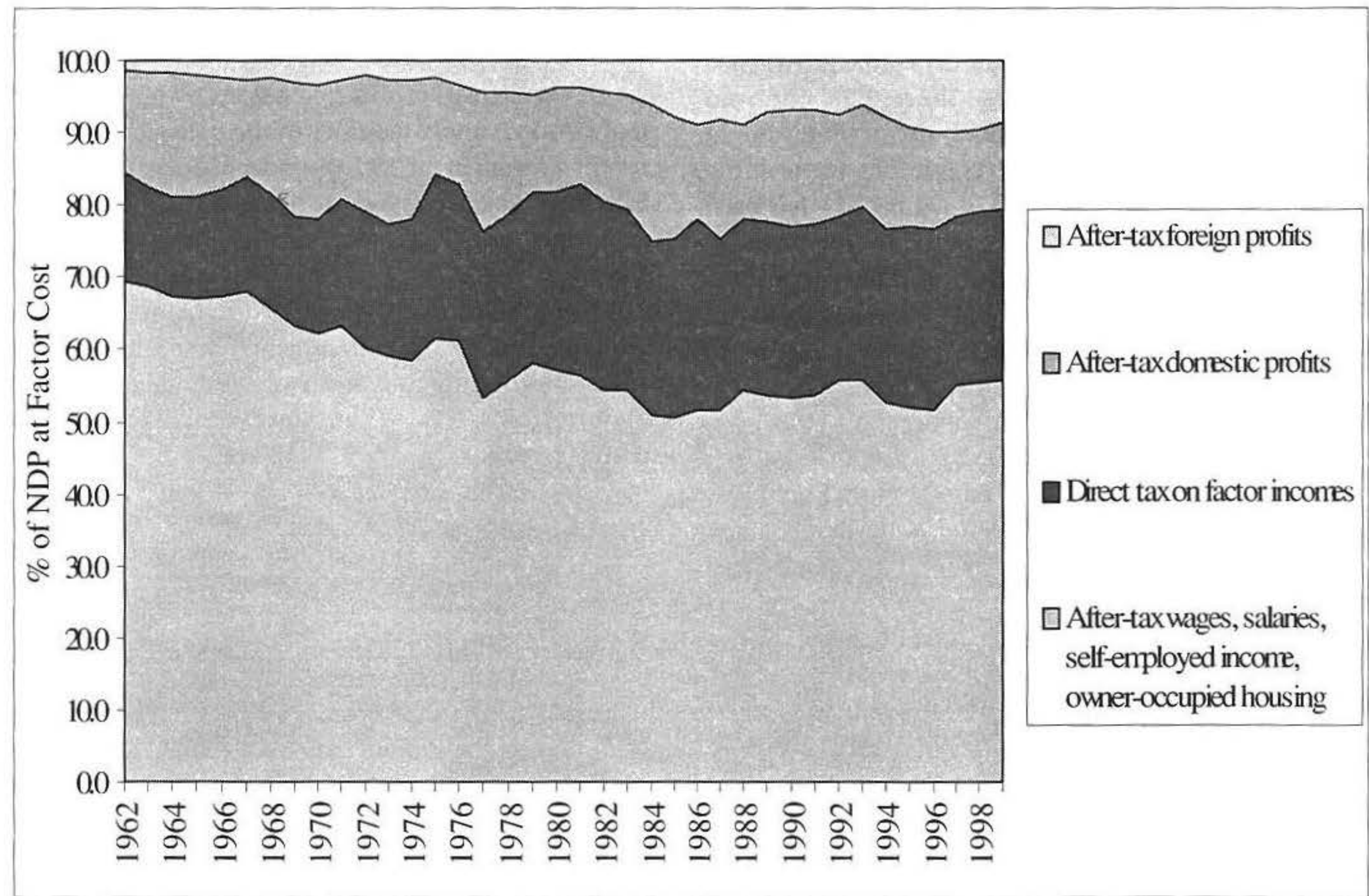


Figure 10. The Four Claimants with Self-Employed Treated as "Capitalists"

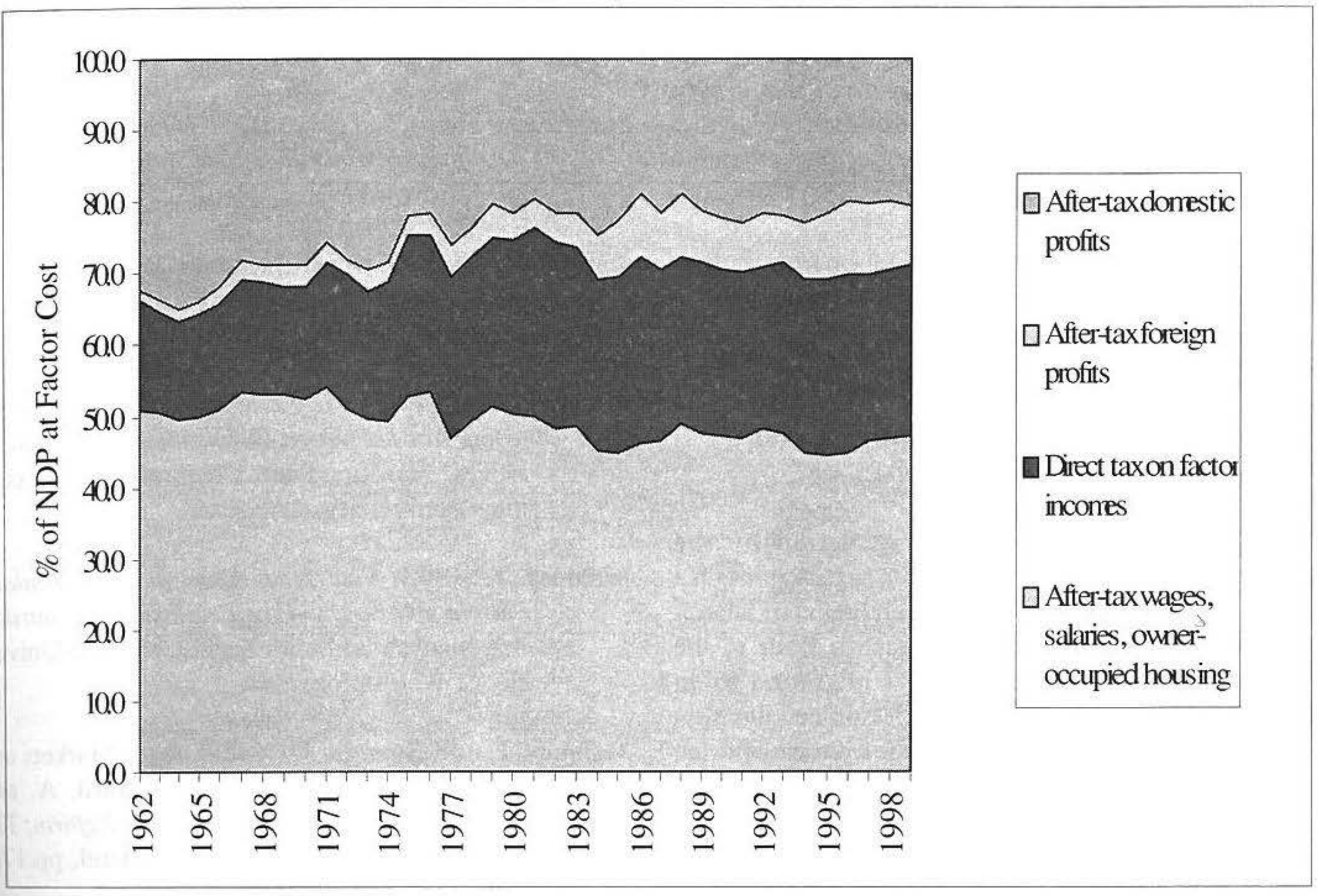

Figure 11. The Four Claimants with Self-Employed and House Owners Treated as "Capitalists"

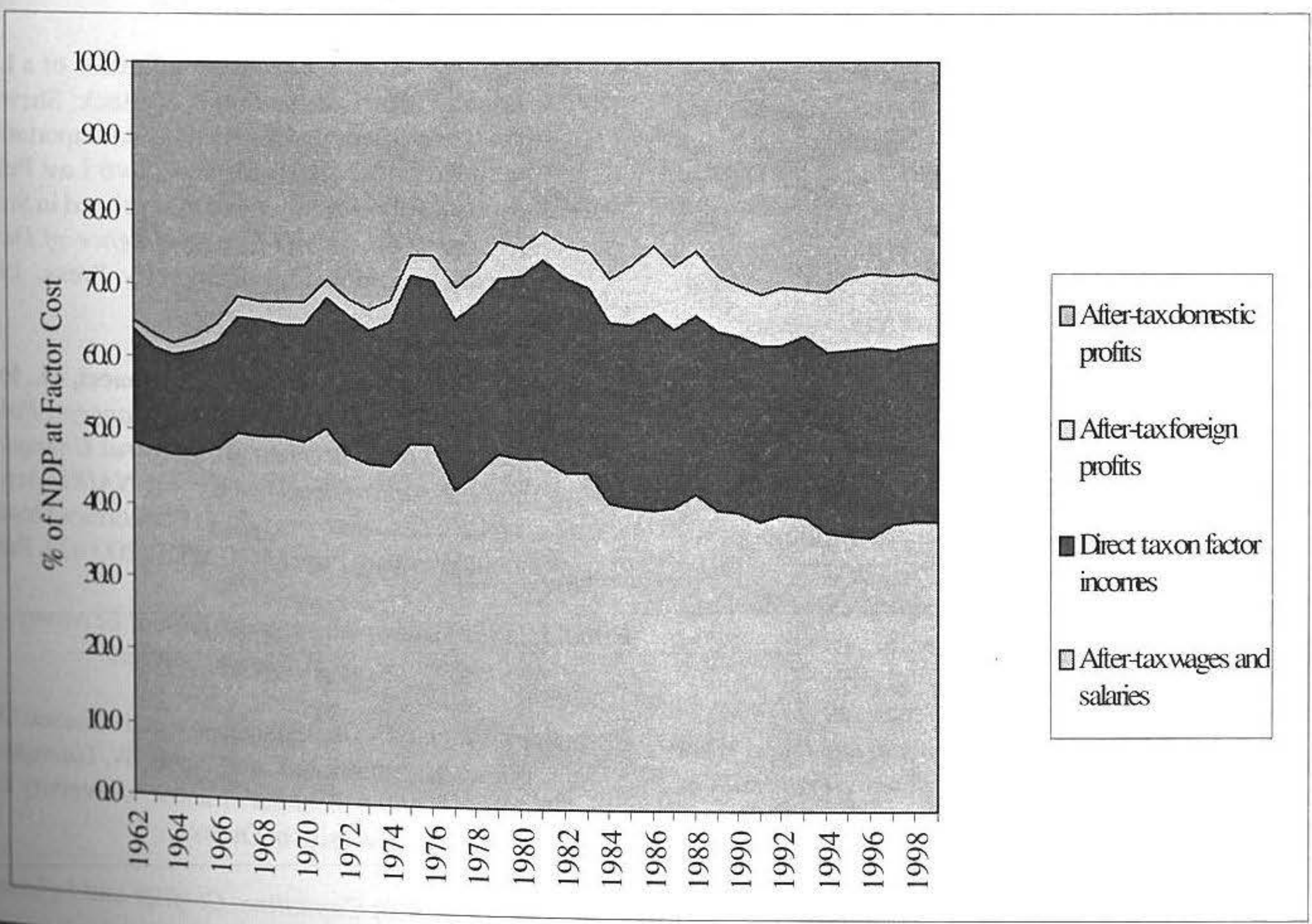


See for example Maloney (1994), (1998); Maloney and Savage (1996). The empirical findings amounted to potential corroboration for Bowley's Law - the "surprise" referred to was among those who believed that labour organisation could affect the distribution of factor incomes. Rima (1996) p. 310 says bluntly that "there is no evidence, either historically or at present, that collective bargaining has raised the wage share" (in the USA).

See Appendix 4 (available on request from author) for further discussion of the Ricardo model.

Bertram and Wells (1983) p.85.

10 The Appendix is available on request from the author.

11 This obviously has to be qualified by the observation that labour was able to pass through a rising tax rate entirely to the purchasers of labour, which implies either a subsistence floor to the income wage rate, or costless migration to an external labour market which determined the New Zealand income wage rate, or the exercise of some degree of market power by labour.

\section{References}

Bertram, G. (1985) Labour's Share of National Income, paper presented to Labour and Employment Workshop, Victoria University of Wellington, September.

Bertram, G. and Wells, G (1983) The Real Wage Controversy. In Buckle, R.A.B. (ed) Inflation and Economic Adjustment: Proceedings of a Seminar Department of Economics, Victoria University of Wellington, pp.68-117.

Blaug, M. (1997) Economic Theory in Retrospect, $5^{\text {th }}$ edition, Cambridge University Press.

Carlin, W. and Soskice, D. (1990) Macroeconomics and the Wage Bargain, Oxford University Press.

Chapple, S. (1993) Kalecki's Macroeconomics, PhD dissertation, Victoria University of Wellington.

Easton, B. (1983) Income Distribution in New Zealand, NZIER Research Paper No 28.

Easton, B. (1990) The Real Wage Debate, 1978-1990. In Morrison, P (ed) Labour, Employment and Work in New Zealalnd the $4^{\text {th }}$ Conference Proccedings, Institute of Geography, Victoria University of Wellington.

Edgren, G., Faxen, K-O, and Odhner, C-E, (1973) Wage
Formation and the Economy, Allen and Unwin, London.

Eltis, W. (1984) The Classical Theory of Economic Growth, Oxford University Press, Oxford.

Hargreaves Heap, S. (1992) The New Keynesian Macroeconomics: Time, Belief and Social Interdependence, Edward Elgar, Aldershot.

Layard, R., Nickell, S. and Jackman, R. (1991) Unemployment, Macroeconomic Performance and the Labour Market, Oxford University Press.

Maloney, T. (1994) Has New Zealand's Employment Contracts Act Increased Employment and Reduced Wages? Working Paper 135, Economics Department, University of Auckland.

Maloney, T. (1998) Five Years After: the New Zealand Labour Market and the Employment Contracts Act, Institute of Policy Studies, Victoria University of Wellington.

Maloney, T. and Savage, J. (1996) Labour Markets and Policy. In Silverstone, B., Bollard, A. and Lattimore, R., A Study of Economic Reform: The Case of New Zealand, North-Holland, pp.173214.

McDonald, T.K. (1978) Wages and Profits: Some Policy Issues, Address to the Twelfth Annual General Meeting of the New Zealand Institute of Economic Research (Inc.), October.

Ricardo, D. (1815) An Essay on the Influence of a Low Price of Corn on the Profits of Stock; Shewing the Inexpediency of Restrictions on Importation: with Remarks on Mr Malthus' Two Last Publications, John Murray, London, reprinted in Sraffa , P. (ed), Works and Correspondence of David Ricardo, Cambridge University Press, 1951 Vol.1.

Richardson, P, Boone, L., Giorno, C., Meacci, M., Rae, D. and Turner, D. (2000) The Concept, Policy Use and Measurement of Structural Unemployment: Estimating a Time Varying NAIRU Across 21 OECD Countries, OECD Economics Department Working Paper ECO/WKP(2000)23, Paris.

Rima, I. (1996) Labor Markets in a Global Economy: An Introduction, M.E. Sharpe, London.

Rosenberg, W. (1980) Unemployment and its Causes: One View. In Shannon, P. and Webb, W. Unemployment and New Zealand's Future, University Extension ,University of Otago.

Rowthorn, R. (1980) Capitalism, Conflict and Inflation, Lawrence and Wishart, London. 


\section{Author}

Geoff Bertram

Senior Lecturer

Economics and Finance

Victoria University

PO Box 600

Wellington

Geoff.Bertram@vuw.ac.nz 